Version imprimée

Capron, Laurent, "15.11 Wisdom of Solomon: Christian Palestinian Aramaic", in: Textual History of the Bible, vol. 2: The Deuterocanonical Scriptures, part 2C (gen. ed. A. Lange, vol. eds. F. Feder and M. Henze; Leiden: Brill, 2019), 535-536

Version en ligne

Capron, Laurent, "15.11 Wisdom of Solomon : Christian Palestinian Aramaic", in: Textual History of the Bible (gen. ed. A. Lange; vol. eds. F. Feder and M. Henze). http://dx.doi.org/10.1163/2452-4107 thb COM 0215110000 (accès payant en janvier 2022)

\title{
15.11 Christian Palestinian Aramaic
}

\subsubsection{The Manuscript Evidence}

A short passage of CPA-Wis survives in a single leaf of a palimpsest manuscript, manuscript Oxford, Bodleian Library, Syr. D. 32 (P), folios $1 a+2 b^{r}$ and $1 b+2 a^{v} .{ }^{1}$ The script dates from the late sixth century C.E. The manuscript is nowadays illegible on the lower part of the first page, and only partly legible on the lower part of the second page. The text preserved covers Wis 9:8b-10:2, but due to the poor state of the leaf, Wis 9:10, 9:12-14 and 9:16 are almost lost, except for few words. Wis 9:17 and 10:1-2 are very fragmentary, and it is impossible to check the manuscript, for the reason mentioned above.

The mention of the beginning of Wisdom of Solomon 10 allows us to presume that the manuscript was not originally a lectionary but contained the whole book of Wisdom of Solomon.

The fragment was acquired in 1893 by the Bodleian Library, and is coming from the Cairo Genizah. ${ }^{2}$ Thus it is very probable that the CPA manuscript came originally from the Monastery of Saint Catherine in the Mount Sinai, as many other CPA texts found in the Cairo Genizah.

\subsubsection{Modern Editions}

The manuscript was first published by Stenning in 1896, with a detailed philological commentary and a translation. ${ }^{3}$ The text was then reedited, with few emendations but without commentary nor translation, by Müller-Kessler and Sokoloff. ${ }^{4}$

\subsubsection{History of Research}

Stenning is the only commentator of this fragment. In his editio princeps, he has given a detailed and precise commentary of the text, but some readings, as well as the knowledge of the language, have been improved so that some remarks do not make sense anymore. In Wis 9:15 (verso, col. a, 1. 5), his

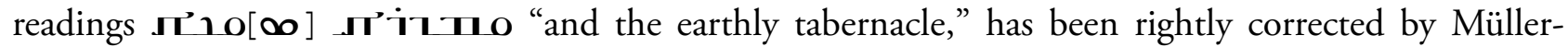

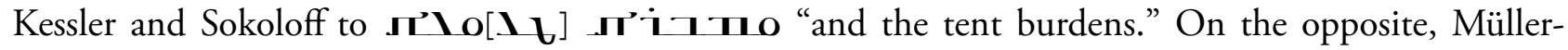

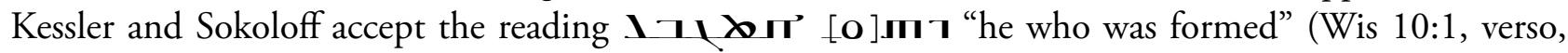

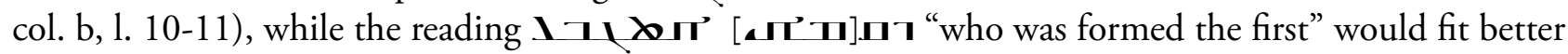
with both the original text $(\pi \rho \omega \tau \dot{\delta} \pi \lambda \alpha \sigma \tau \nu)$ and the Christian Palestinian Aramaic grammar.

1. Images available at https://genizah.bodleian.ox.ac.uk/catalog/volume_224\#MS_Syr_d_32_P-item1-item2 last accessed January 2022.

2. Gwilliam, Crawford, and Stenning, Biblical and Patristic Relics, 5.

3. Gwilliam, Crawford, and Stenning, Biblical and Patristic Relics, 21-28.

4. Müller-Kessler and Sokoloff, The Christian Palestinian Aramaic Old Testament 1, 200-01. It has to be noticed that, in this reedition, the remaining words of Wis 9:10 are misplaced, as they appear to be on 11. 21-22 of the column a, and not on 11. 15-16: this is due to a misunderstanding of the edition of Stenning, where three lines of dots have been used to indicate a large lacuna in the text, but without any line number. The commentary of Stenning to 11. 11-20 says that these lines "are absolutely illegible." The words here deciphered fit perfectly with the last words of Wis 9:10, while the edition of MüllerKessler and Sokoloff suggests that some text is missing after them and while, at the same time, there would not be enough place in 11. 12-14 to contain the text of Wis 9:10. 
Furthermore, in several places, Stenning has proposed reconstructions for words lost in lacunae. MüllerKessler and Sokoloff cautiously reedited these lacunae making reconstructions only when at least a part of a word was still extant. In one case, however, they may have considered the reconstruction as obvious, i.e. in Wis 9:15 (verso, col. a, 1. 8): Stenning proposed mX9 translation of the Greek $\pi 0 \lambda v \phi \rho \dot{v} v i \delta \alpha$.

\subsubsection{Relevant Variants with LXX-Wis}

It is quite remarkable that the CPA version follows very closely LXX-Wis (cf. 15.2) but in one case our

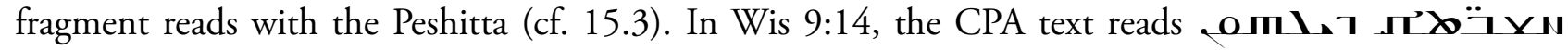

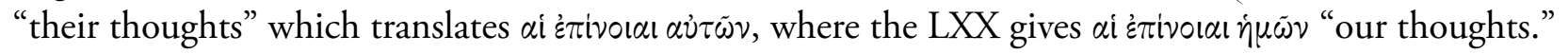

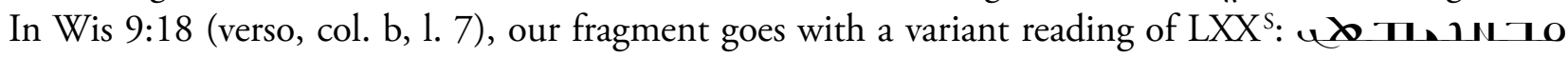

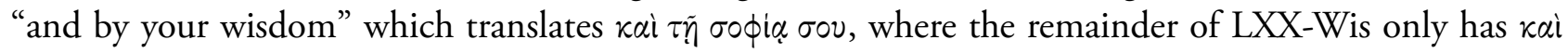

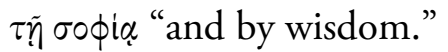

In two places, Greek future tenses are rendered by CPA as present tenses, i.e. in Wis 9:11 (recto,

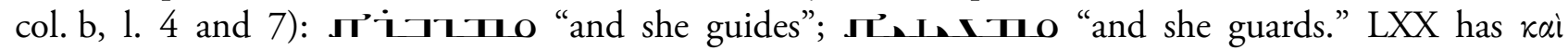

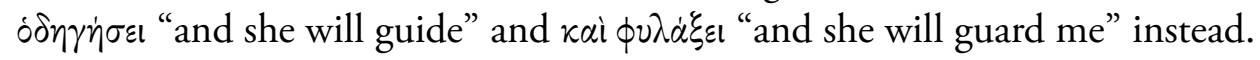

\section{Bibliography}

Gwilliam, G.H., Crawford, F., and Stenning, J.F., (eds.), Biblical and Patristics Relics of the Palestinian Literature from Mss. in the Bodleain Library and in the Library of Saint Catherine in the Mount Sinai (Anecdota Oxoniensia 2 Semitic Series 9; Oxford: Clarendon Press, 1896).

Müller-Kessler, Chr., and Sokoloff, M. (eds.), The Christian Palestinian Aramaic Old Testament and Apocrypha Version from the Early Period (Corpus of Christian Palestinian Aramaic 1 ; Groningen: Styx Publications, 1997). 